Available online at: http://proceeding.rsfpress.com/index.php/ic-smart/index

Proceeding on International Conference of Science Management Art Research Technology

(IC-SMART)

Volume 1 Number 1 (2020): 58-63

\title{
The Effect of Locus of Control on The Performance of Government Organizations with The Internal Auditor Empowerment Variable as a Moderation Variable
}

\author{
Dwi Kriswantini, Christina Sososutiksno
}

Faculty of Economics and Business, Pattimura University, Ambon; E-mail address_kriswantini@gmail.com; E-mail address_chr_sososutiksno@yahoo.com

\begin{abstract}
As an organization in the public sector, local governments must have a performance that leads to the interests of the public at large, thus encouraging the government to always be responsive to the development of their environment so as to provide the best service, transparency, and quality behavior, as well as good job distribution to the government. This study aims to test the effect of locus of control on the performance of government organizations empirically and to empirically test the empowerment of internal auditors for moderating the relationship between locus of control and the performance of government organizations. The population used in this study is the internal government auditors or Auditor Functional Officials who work at the Inspectorate Office of Maluku Province and Ambon City. The respondent in this study were 60 respondents, consisting of supervisory auditors, first, young, and middle. The results of data processing indicate that the locus of control has a positive effect on organizational performance. The effect of the control locus construct was positive (0.608) and significant at $0.000(5,633>1,661)$. The results of data processing indicate that the empowerment of internal auditors moderates the relationship between locus of control and organizational performance. The effect of the LOC*PAI interaction construct is positive (0.635) and significant at $0.001(3.542>1.661)$.
\end{abstract}

Keywords: Locus Of Control, Empowerment of Internal Auditors, and Organizational Performance.

This is an open access article under the CC-BY-NC license.

\section{INTRODUCTION}

Local governments demand that the performance of public sector organizations be oriented towards the interests of the community and always be responsive in terms of environmental development by striving to provide quality and transparent services, as well as a good division of tasks within the government. The performance measurement system is expected to increase transparency, accountability, and efficiency, as well as the effectiveness of public organizations. Public institutions are expected to have a good performance, which is shown by stewardship and accountability of the institutions to the public resources they manage.

Government auditors are auditors in charge of auditing state finances in government agencies. In Indonesia, this audit is carried out by the Supreme Audit Agency (BPK). Government Internal Auditors often receive sharp scrutiny regarding their performance. In dealing with highly motivated 
internal auditors, empowerment is one of the methods recommended by many researchers in the accounting field to increase internal auditor motivation.

The process of reorganizing government audit departments influences the attitudes taken by their auditors. The thing that might happen is that the auditors may behave defiantly in completing the work (audit) that is given to them. To avoid such auditing practices, a personality or variable is needed that can influence and control such auditors' behavior, and that personality or variable is the Locus of Control (LOC).

Noe et al. (1994) empowerment is the giving of responsibility and works authorization to make decisions regarding all product development and decision making. With empowerment, employees are given the opportunity and ability to plan, implement, and control the implementation of the work plan, which is the responsibility of the employee or group. The implementation of responsibilities must also be balanced with a smart level of ability and knowledge of the tasks to be carried out.

This study aims to test the effect of locus of control on the performance of government organizations empirically and also to obtain empirical evidence of the empowerment of internal auditors in moderating the effect of locus of control on the performance of government organizations.

The object of this research is the Inspectorate Office of Maluku Province and Ambon City. Based on what has been described above, the authors are interested in examining more deeply the effect of locus of control on the performance of government organizations and the influence of empowering internal auditors to moderate the relationship between locus of control and the performance of government organizations.

\section{LITERATURE REVIEW}

Attribution Theory

Attribution Theory is a theory that discusses the efforts made to understand the causes of our behavior and that of others. Fritz Heider (1958), attribution theory, is a theory that explains a person's behavior. Is the behavior caused by dispositional factors (internal/internal factors), such as traits, character, attitudes, and so on, or is it caused by external circumstances, such as certain situations or circumstances that force someone to do certain actions (Luthans, 2005)

\section{Motivation Theory}

Robbins (2007) motivation is the readiness to make a high effort towards organizational goals that are conditioned by the ability of these businesses to meet individual needs, of the three elements of opinion are the goals and needs of the business. Meanwhile, according to Gibson (1994) as quoted by Kartika and Wijayanti (2007), motivation is a concept that describes the forces that exist within a person who will initiate or direct their behavior

\section{Locus Of Control (LOC)}

Locus of Control, according to Spector (as quoted by Munir and Sajid, 2010), is defined as a reflection of an individual's tendency to believe that he controls events that occur in his life (internal) or control over events that occur in his life comes from other things, for example, the power of others (external). Erdogan's Locus of Control (as cited by Kutanis, Mesci, and Ovdur, 2011) includes the idea that individuals, throughout their life, analyze events as a result of their behavior or they believe that these events are the result of chance, fate, or forces beyond their control.

Empowerment 
Wibowo (2012 ) states that employee empowerment is a process to make individuals more empowered in solving a problem. Fitriah and Sudibya (2015) state that empowerment is an effort to make human resources more fully responsible for what they do.

Organizational Performance

Indra's (2006) performance is a description of the achievement of the implementation of an activity/program/policy in realizing the goals, objectives, mission, and vision of the organization. Performance is often translated as appearance, work performance, level of success, or achievement of a target, which shows the implementation of the results of an individual or group of individuals who are assessed based on the measures of a performance measurement system.

The Effect of LOC on Organizational Performance

Individuals with Locus of Control have a belief that there is a strong relationship between effort and results. Internal locus of control refers to the perception that positive or negative events occur as a consequence of one's own actions or deeds and under self-control. These individuals will show better performance in situations that allow them to implement actions that are considered appropriate in a job, Hyatt and Prawitt (2000) as cited by Patten (2005). Activity information is also expected to affect performance.

\section{H1: Locus of Control affects Government Organization Performance}

The Effect of Internal Auditor Empowerment on the Relationship between Locus of Control and Organizational Performance

Government organizations must pay full attention in order to increase the trust of their employees so that each employee will have a commitment to the organization, and if the organizational commitment is owned, loyal employees will be found who are able to work well for the benefit of the organization. This situation is good for the achievement of organizational goals because the organization has the full support of its members so that it can contribute to the goals that the organization prioritizes. Robbins and Judge (2007) define organizational commitment as a condition in which individuals side with the organization and its goals and desires to maintain membership in the organization.

H2: Internal Auditor Empowerment affects the relationship between Locus of Control and Government Organization Performance

\section{RESEARCH METHODOLOGY}

Population and Sample

The population used in this study is the internal government auditors or Auditor Functional Officials who work at the Inspectorate Office of Maluku Province and Ambon City. Respondents in this study were 60 respondents, consisting of supervisory auditors, first, young, and middle.

The sampling technique in this study was carried out by using convenience sampling, which is a convenient sampling which is carried out by selecting free samples at will (Jogiyanto, 2004). The sample used in this study is the internal auditor or Auditor Functional Officer.

The method of collecting primary data from respondents was carried out by survey, namely by collecting primary data from a sample using a questionnaire instrument by providing a list of written questions to the respondent. Primary data in this study were obtained through distributing questionnaires given to respondents, namely internal auditors who work at the Inspectorate of Maluku Province and Ambon City. 
Data Analysis Method

In analyzing the hypothesis in this study, the data analysis method used is Moderated Regression Analysis (MRA) by using the absolute value difference test. The reason for using this interaction test is the presence of a moderating variable in this study. The absolute value difference test is done by finding the difference in standardized absolute values between the two independent variables. If the difference in absolute value between the two independent variables is positive, then the variable moderates the relationship between the independent variable and the dependent variable. The following is a regression equation in which the dependent variable, namely Government Organizational Performance, is regressed into the Locus of Control and Internal Auditor Empowerment variables:

$\mathrm{KOP}=\mathrm{a}+\mathrm{b} 1 \mathrm{LOC}+\mathrm{b} 2 \mathrm{PAI}+\mathrm{b} 3($ LOC-PAI $)+\mathrm{e}$

Where:

$\mathrm{KOP}=$ Performance of Government Organizations LOC $=$ Locus of Control

$\mathrm{PAI}=$ Empowerment of Internal Auditors

$\mathrm{e}=$ error

$\mathrm{a}=$ constant

\section{FINDING AND DISCUSSION}

The Effect of Locus of Control with Organizational Performance

The first hypothesis (H1) states that the locus of control has a positive effect on organizational performance. The results of data processing indicate that the locus of control has a positive effect on organizational performance. The effect of the locus of control construct was positive (0.608) and significant at $0.000(5,633>1,661)$.

Based on the foregoing, it can be concluded that the first hypothesis proposed in this study is proven. In other words, there is an influence between the locus of control on organizational performance. This means that the higher the internal locus of control, it can actually encourage employee performance improvement. This situation is because employees can empower both internal and external locus of control, so as to create competitive working conditions and strive to always be able to face problems in completing their work better, both in terms of quality, quantity, timeliness, and independent performance.

The Effect of Internal Auditor Empowerment on the Relationship between Locus of Control and Government Organization Performance

The second hypothesis ( $\mathrm{H} 2)$ states that the empowerment of internal auditors moderates the relationship between locus of control and organizational performance. The results of data processing indicate that the empowerment of internal auditors moderates the relationship between locus of control and organizational performance. The effect of the LOC*PAI interaction construct was positive $(0.635)$ and significant at $0.001(3.542>1.661)$. 
Proceeding on International Conference of Science Management Art Research Technology (IC-SMART), Vol. 1 (1), 58-63

The Effect of Locus of Control on The Performance of Government Organizations with The Internal Auditor Empowerment Variable as a Moderation Variable

Dwi Kriswantini, Christina Sososutiksno

Based on the foregoing, it can be concluded that the form of mediation of this model is full mediation, meaning that the empowerment of internal auditors is the only variable that mediates the effect of locus of control on the performance of government organizations.

\section{CONCLUSION AND FURTHER RESEARCH}

From the results of data analysis that have been described in the previous chapter of this study, it can be concluded that the locus of control variable has a positive effect on the performance of government organizations. This means that a good locus of control in internal auditors will also affect the performance of good government organizations.

The internal auditor empowerment moderating variable has an effect on the relationship between the locus of control variable and the performance of government organizations. This means that internal auditors have a good locus of control, and the government empowers internal auditors, so the performance of government organizations will be better.

For further research, it is suggested to increase the number of participants in public organizations or all government audit officials such as the Supreme Audit Agency (BPK) and the Government Audit Board (BPKP) in this study. Furthermore, it can expand the research model by adding other variables that can affect the performance of government organizations.

This research has several limitations. Firstly the respondents of this study are limited to government auditors who work at the Inspectorate Office of Maluku Province and Ambon City. It is possible that this research will show different results if it is carried out on all employees of public organizations or all government audit officials such as the Audit Board Finance (BPK) and the Government Audit Board (BPKP). Selection of samples within a relatively small scope and using only one particular area, thus reducing the generalizability of these findings. This research data is generated from instruments based on the perception of the respondents' answers. This will cause problems if the respondent's perception is different from the real situation. The actual number of samples is still relatively small, even though it meets the minimum required number.

\section{REFERENCES}

Bastian, Indra. 2006. Public Sector Accounting: An Introduction . Jakarta: Erlangga.

Fitriah, and IGA Sudibya. 2015. The Effect of Employee Empowerment and Job Satisfaction on the Organizational Commitment of the Regional Company Secretariat of the Denpasar City Market. E- Journal of Management of Udayana University , 4 (11), H: 3478-3507.

Gibson, James L., Ivancevich, John M., Donnely James H. Jr. 1996. Organizational Process Structure Behavior, 8 th ed, Bandung, Binarupa Aksara.

Jogiyanto HM 2004. Computer Theory and Applications. Andi Offet. Yogyakarta.

Kartika, Indri and Provita Wijayanti. 2007. Locus of Control as Antecedents of Employee Performance Relationship and Dysfunctional Behavior Acceptance . X. Makassar National Accounting Symposium .

Kutanis, Rana Ozen, Muammer Mesci and Zeynep Ovdur. 2011. The Effects of Lotus of Control on Learning Performance: A Case of an Academic Organization . Turkey: Journal of Economic and Social Studies.

Luthans, Fred. 2005. Organizational Behavior 10th Edition . Translation: Vivin Andhika, et al, Yogyakarta: ANDI.

Munir, Saima and Mehsoon Sajid. 2010. Examining Locus Of Control (LOC) as a Determinant of Organizational Commitments among University Professors in Pakistan 
. Journal of Business Studies Quarterly Vo 1.1 (3), 78-93, ISSN 2152-1034.

Noe, Raymond A, et al. 2011. Fundamentas of Human Resource Management . 4th ed, New York: McGraw-Hill Companies, Inc.

Robbins, Stepen. 2007. Organizational Behavior: Translation: Benyamin Molan. New Jersey Prentice Hall, Inc.

Robbins and Judge. 2008. Organizational Behavior, Issue Twelve, Publisher Salemba Empat: Jakarta.

Patten, MD 2005. An Analysis of The Impact of Locus of Control on Internal Auditor Job Performance and Satisfaction . Managerial Auditing Journal, Vol. 20 No: 9, 1016- 1029.

Wibowo, Prasetyo. 2012. Impact Analysis of Locus of Control on Work Pressure, Job Satisfaction and Auditor Performance. Undergraduate Thesis (Unpublished). Indonesian education university. Bandung. 